\title{
PREZENȚA SÂRBILOR ÎN BANATUL ROMÂNESC PE BAZA DOVEZILOR DE IMPRIMOGRAFIE CHEMO-MECANIC $\breve{A}^{3}$
}

Prezenta lucrare aduce dovezi noi despre prezența Sârbilor în Banatul Românesc. Așa cum s-a precizat în Ishodišta nr. 5, prezența Sârbilor în Banatul Românesc este dovedită începând cu anii 1182, odată cu sosirea călugărului Ilarie din Țârvia (= Sârbia/Serbia) - ziditorul mănăstirii Căvăranului, urmată în anii 1342 de egumenul Elefterie, cel care va zidi mănăstirea Zlatița - cu hramul Sfântului Sava -, respectiv de cneazul Lazăr Sârbu, care, după zidirea mănăstirii Vodița din anul 1371, va face danie mănăstirii zece sate din Țârvia. Lui îi urmează în anul 1438 cneazul Milan, care va zidi mănăstirea Cusici, unde se vor așeza călugării sârbi sosiţi din Serbia. În anul 1486 despotul sârb Ioan Brancovici va înzestra și rezidi mănăstirea Partoșului, iar în anul 1498 Dimitri Iakcşici-Sârbul va înzestra biserică de piatră de la Hodoș.

Prezenta lucrare aduce la lumină prezența Sârbilor prin trei documente imprimografiate:

1. Manuscrisul lui popa Iancu ot Iaz - 27 iulie 1604;

2. Manuscrisul egumenului Gavrilă de la mănăstirea Sfântul Gheorghe din Caransebeș - 23 septembrie 1608;

3. Manuscrisul diacului Martin din Petrovo Selo - 27 septembrie 1691, documentul face referire la una din marile migrații ale Sărbilor (Seoba Srba).

Cuvinte cheie: Căvăran, Cneazul Milan, Cneazul Lazar, Dimitri Iacșici, imprimografie, Ioan Brancovici, Serbia, Sfântul Sava.

$\mathrm{Nu}$ vom analiza aici textele apocrife, criptograme sau manuscrise palimpsest și nici nu vom teoretiza problematica steganografiei sau pe cea a criptografiei. Obiectul cercetărilor noastre nu are tangență cu fascinanta teorie a memoriei apei (o descoperire capabilă să devină realitate, dar care - aidoma proiectului de captare a energiei electrice din univers, descoperirea dezvoltat de celebrul cercetător Nikola Tesla în urmă cu peste 100 de ani, își așteaptă smerită rândul și ... decizia politică, proiectul fiind deocamdată blocat de marile industrii ale lumii).

\footnotetext{
${ }^{1}$ arb1.romania@gmail.com

${ }^{2}$ Lucrarea elaborată și finanțată de Asociația Românilor din Balcani, în cadrul proiectului științific „Prezervarea ființei naționale a Românilor”.

${ }^{3}$ Procedeul a fost înregistrat la Oficiul de Proprietate intelectuală din Benelux (nr. 117333/10.05.2019)
} 
Ne vom apleca aici asupra manuscriselor românești pierdute, indiferent de modul în care au dispărut, dar care pot fi reconstituite prin analiza unor suporturi în care au fost prezervate originalele, cele care au stat în contact cu materialele denumite de noi generic mama-surogat ${ }^{4}$ (în toate cazurile când originalul era în contact fizic direct cu un astfel de material). Efectul pare imposibil dar în realitate el se produce.

Operaţiunea constă în descifrarea literelor sau a resturilor de semne și litere întipărite fragmentar sau în totalitatea lor în "memoria" mamei-surogat, respectiv în- sau pe suportul cu care a fost păstrat originalul (v. foto jos). Hârtia surogat folosită ca materie primă, cea care a servit la rememorarea manuscrisului pierdut, nu trebuie să fie neapărat examinată prin prisma unui produs rezultat din prelucrarea celulozei. Pentru că scrisul poate fi prezervat destul de bine și pe alte suporturi materiale: lemn, lut, ceramică, piatră și chiar pe unele metale - cu precădere cuprul - dar și pe părțile unor produse animale, cum sunt pielea umană sau animală, atunci când acestea au fost inițial prelucrate până la calitatea unui pergament vellum 5 .

Ca și în cazurile precedente, vom analiza aici doar artefactele existente în inventarul propriu, fără a intra în sfera speculațiilor teoretice atât de îndrăgite de savanții lumii moderne.

Fiind în posesia unor manuscrise originale (spre ex. signatura 1451/7108 (= 1599), depozitate în condițiile mai sus enunțate, am constatat existența pe hârtie a reminiscențelor cernelii sepia, provenite de la textul original, care în acest fel s-a autoamprentat pe hârtia cu care a venit în contact pe perioada conservării sau depozitării, prin efectul absorbției chimice pe de o parte și a imprimografiei mecanice (de apăsare), pe de altă parte. În acest mod manuscrisul original a eliberat o cantitate nu prea consistentă din conținutul său, procesul având loc și prin difuzia cernelii către manuscrisul surogat. Conținutul a fost trasmis în cantitate suficientă pentru a putea descifra textul imprimat. Am obținut astfel o copie fidelă după originalul arhivat de veacuri, prin reproducere în original, oglindă sau în ambele moduri, după caz.

În aceste condiţii, coeficienții de permeabilitate și umiditate, favorizați de temperatura ambientală adecvată și prezența unei forțe de apăsare mecanice corespunzătoare, precum și de existența unei texturi ideale a hârtiei, au creat solubilitatea și și au permis difuzia sepiei prin microporii hârtiei originale, cerneala migrând din manuscris către ambalaj. Anumite condiții speciale țin și de natura hârtiei - dacă aceasta la fabricare a trecut prin presă (aşa-numitul proces de calandrare), hârtia devenind netedă (satinată), înlesnindu-se astfel permeația cernelii. Fenomenul se datorează nu în ultimul rând forței de apăsare exercitate

\footnotetext{
${ }^{4}$ Un produs care poate înlocui sau reproduce, deși într-o forma inferioară, un alt produs cu care are anumite proprietăţi comune (cf. germ. Surrogat).

${ }^{5}$ Piele animală, cu precădere de ied, dar și de miel, extrasă înaintea termenului de fătare și apoi prelucrată (tăbăcită) la cele mai înalte standarde.
} 
de manuscrisele așezate deasupra hârtiei dar și a compoziției materialului de conservare, dar și a câtorva condiții adiacente, asupra cărora nu vom insista aici.

Cazul nr. 1 - Manuscrisul imprimografiat în anul 1604 - signatura 1742/1604

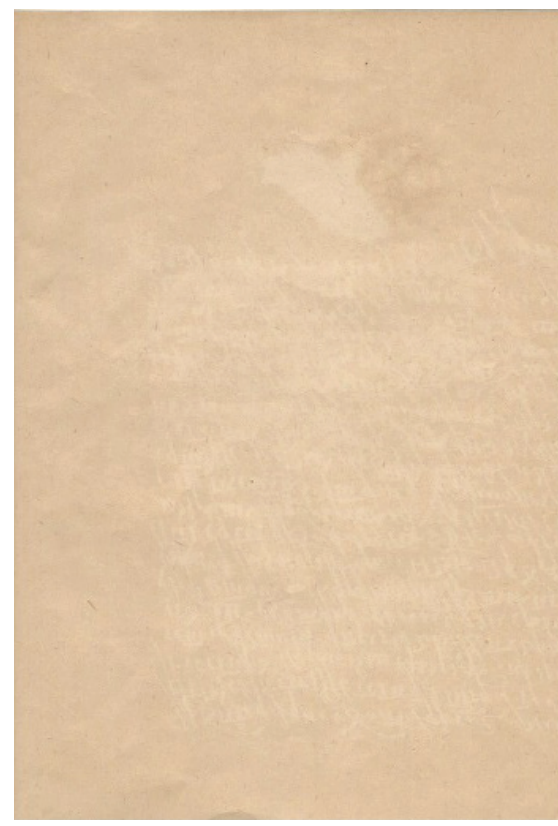

Faza 1 - Imprimografiere în oglindă

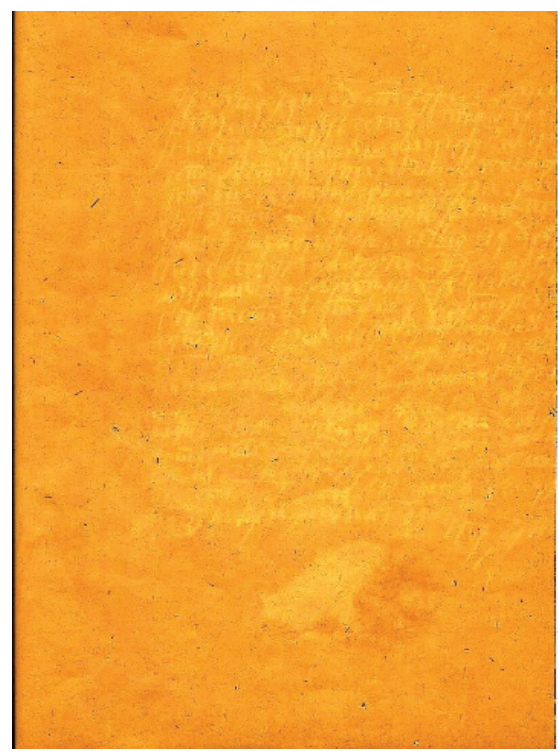

Faza a III-a - filtrarea hârtiei

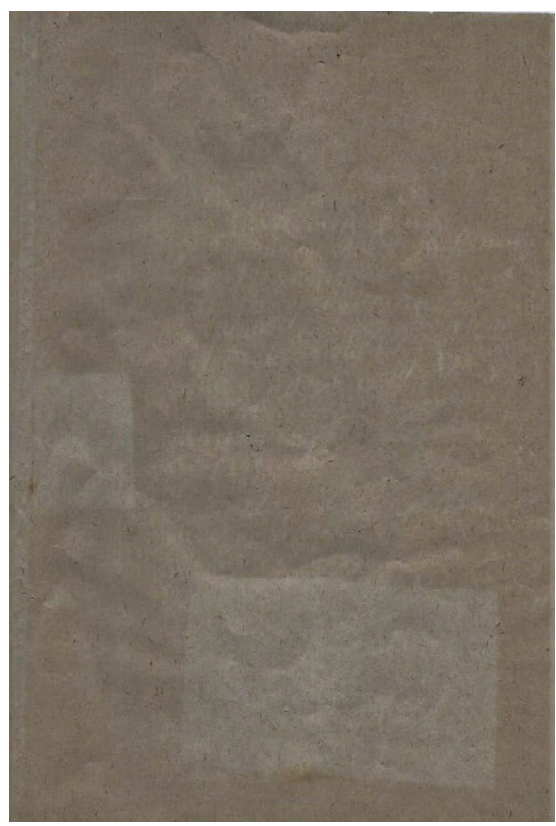

Faza a II-a - Întoarcerea textului

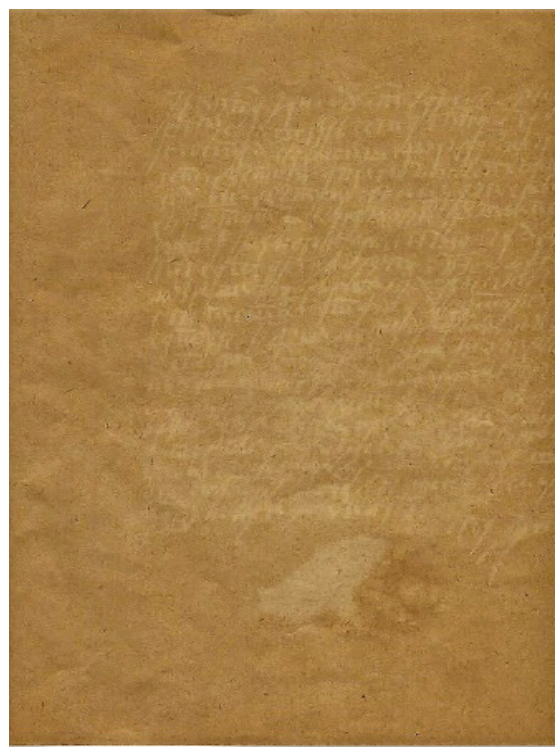

Faza a IV-a - pregătirea manuscrisului în spectrul de culori adecvat descifrării 


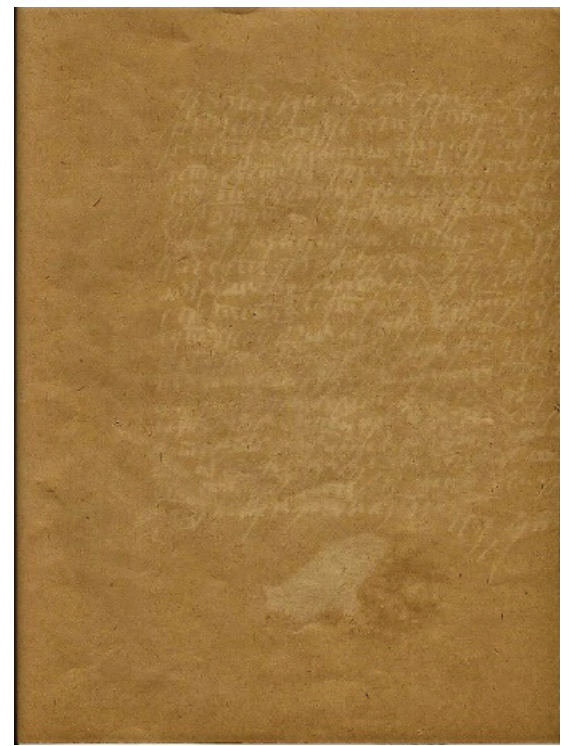

Faza a V-a - pregătirea textului pentru transcriere

Transcrierea textului

\begin{tabular}{|c|c|}
\hline 1 & 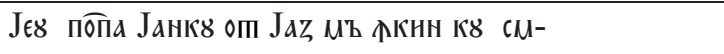 \\
\hline 2 & єрєнне сър४П дрЊППа єПППа Прокопне ал \\
\hline 3 & 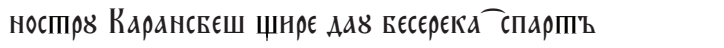 \\
\hline 4 & єСПє Аъ ППОП аПрннсъ БАъСПъМацн дъ Д- \\
\hline 5 & 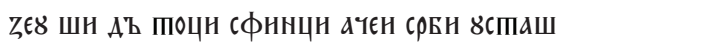 \\
\hline 6 & 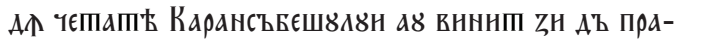 \\
\hline 7 & 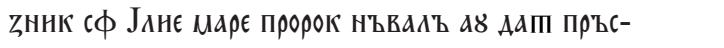 \\
\hline 8 & 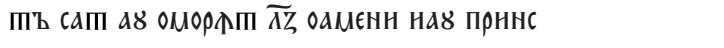 \\
\hline 9 & 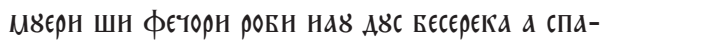 \\
\hline 10 & 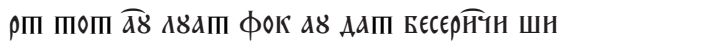 \\
\hline 11 & 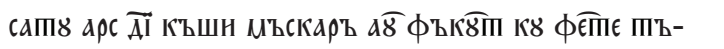 \\
\hline 12 & 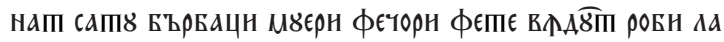 \\
\hline 13 & 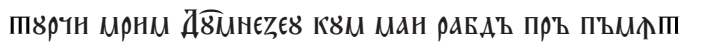 \\
\hline 14 & 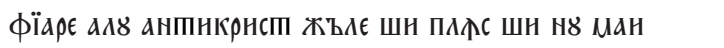 \\
\hline 15 & 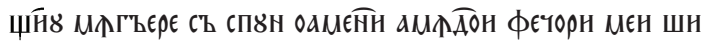 \\
\hline 16 & 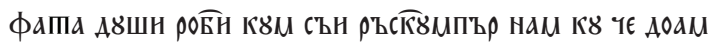 \\
\hline 17 & 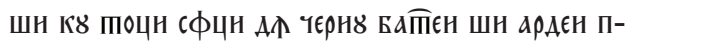 \\
\hline 18 & 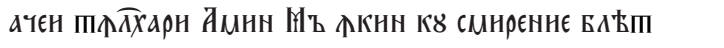 \\
\hline 19 & 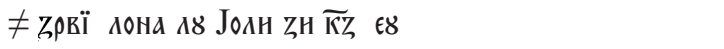 \\
\hline 20 & 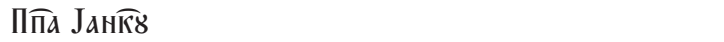 \\
\hline
\end{tabular}




\section{Transliterare}

Eu,popa Iancu otlaz,măînchin cusmirenie, sărutdreapta episcopa Procopie al nostru Caransbeș. Știre dau: besereca spartă este, dă tot aprinsă, blăstămați dă Dumnezeu și dă toți sfinții, acei Sârbi, ustași dîn cetatea Caransăbeșului, au vinit zi dă praznic, sf. Ilie Mare Proroc, năvală au dat prăstă sat, au omorât 37 oameni, au prins muieri și feciori, robi i-au dus. Besereca au spart, tot au luat, foc au dat beserci și satu ars 14 căși. Măscară au făcut cu fete, tăiat satu bărbați, muieri, feciori, fete, vândut robi la Turci. Măritul Dumnezeu cum mai rabdă pră pământ fiare alu antihrist? Jăle și plâns și nu mai știu mângâiere să spun oameni amândoi feciorii mei și fata duși robi cum să-i răscumpăr n-am cu ce doar și cu toți sfți dîn ceriu bate-i și arde-i p-acei tâlhari, Amin. Mă închin cu smirenie în anul 7112 (= 1604), lu(na) ioli, zi 27, Eu, Prota Iancu.

Cazul nr. 2 - Imprimografie din anul 1608 (signatura 1679/1608)

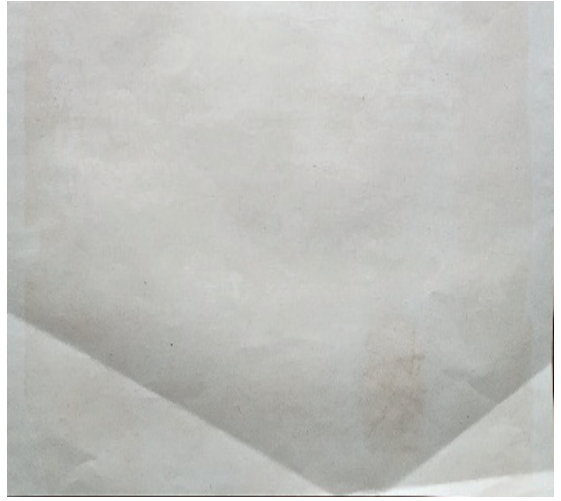

Faza 1 - Imprimografiere în oglindă

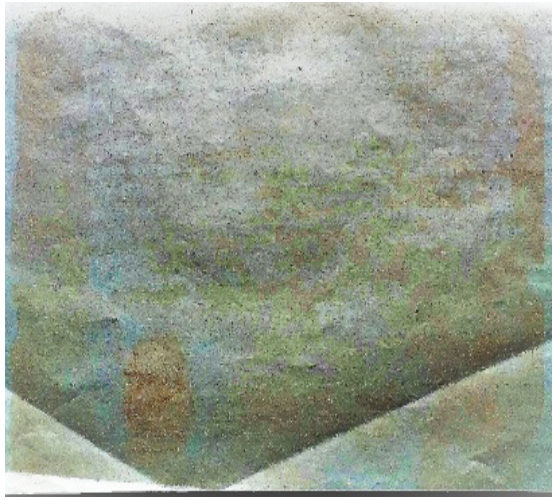

Faza a III-a - filtrarea hârtiei

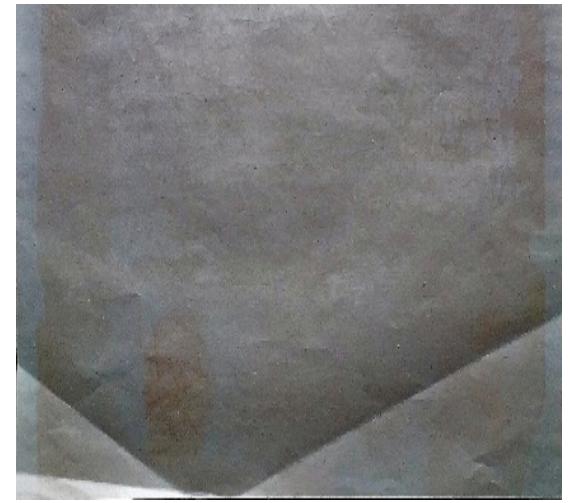

Faza a II-a - Întoarcerea textului

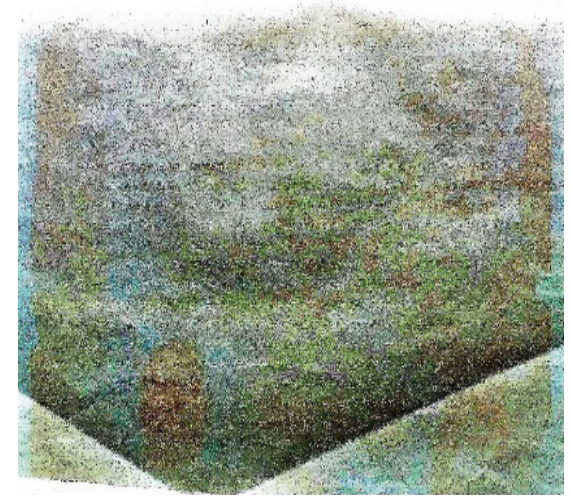

Faza a IV-a - pregătirea manuscrisului în spectrul de culori adecvat descifrării 


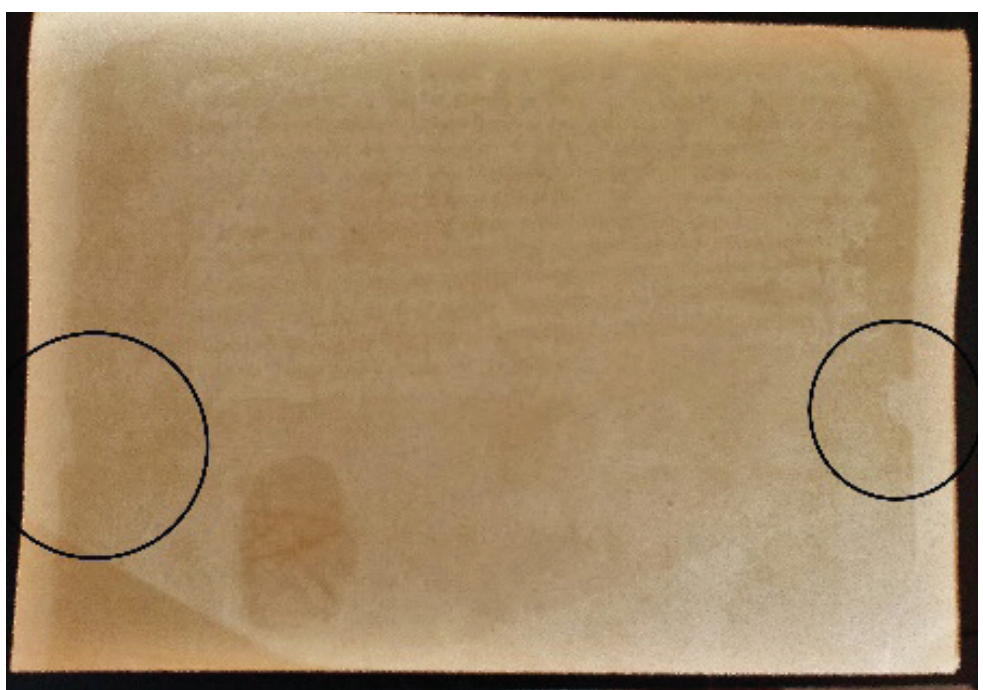

Faza a V-a - pregătirea textului pentru transcriere ${ }^{6}$

\section{Transcriere}

\begin{tabular}{|c|c|}
\hline 1 & 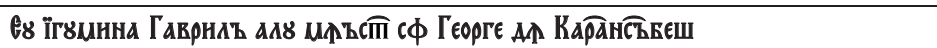 \\
\hline 2 & 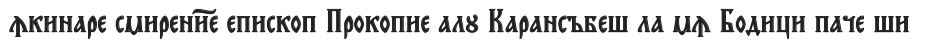 \\
\hline 3 & 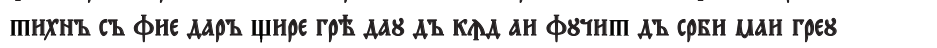 \\
\hline 4 & 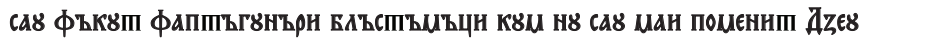 \\
\hline 5 & 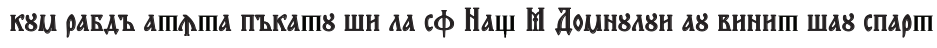 \\
\hline 6 & 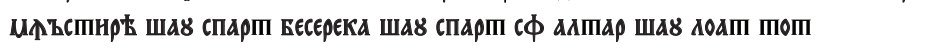 \\
\hline 7 & 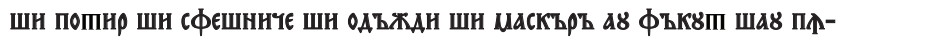 \\
\hline 8 & 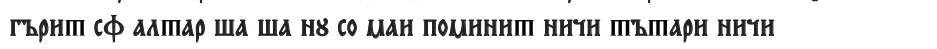 \\
\hline 9 & 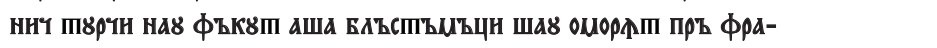 \\
\hline 10 & 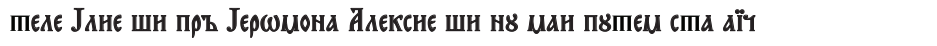 \\
\hline 11 & 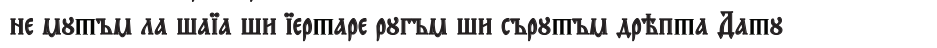 \\
\hline 12 & 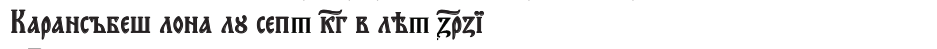 \\
\hline 13 & ГаврнАъ єГ४Мнна \\
\hline
\end{tabular}

\section{Transliterare}

Eu igumina Gavrilă alu mânăst. Sf. Gheorghe dîn Caransăbeș, închinare smirită episcopi Procopie alu Caransăbeș la mân. Vodiți, pace și tihnă să fie. Dară știre grea dau, dă când ai fugit dă Sârbi mai greu s-au făcut, faptăgunării blăstămății cum nu s-au mai pominit, Dumnezeu cum rabdă atâta păcatu și la sf. Nașt. M. Domnului au vinit ș-au spart mănăstiria, și au spart besereca, ș-au spart

\footnotetext{
${ }^{6}$ Cele două cercuri reprezintă marcarea fizică a unor caracteristici ale manuscrisului, în vederea identificării în cazul redescoperirii ulterioare a originalului.
} 
sf. altar, ş-au loat tot: și potir, şi sfeşnice, şi odăjdii. Şi mascără au făcut, ș-au pîngărit sf. altar. Ş-aşa nu so mai pomenit, nici Tătari, nici nici Turci n-au făcut așa blăstămății. Ș-au omorât pră fratele Ilie, și pră Iromona Alexie, și numai putem sta aici, ne mutăm la Șaia. Și iertare rugăm, și sărutăm dreapta. Datu Caransăbeș, lona lu sept 23, în anul 7117 (=1608). Gavrilă Igumina.

Exemplul imprimografic nr. 3 - din anul 1691 -, cel mai reuşit din întreagă noastră colecție, a beneficiat de toate condițiile chimico-fizice, fiind astfel nevoiți doar să aplicăm fazele I și V - întoarcerea textului din poziția de citit în oglindă în poziția originală și coborârea sa în vederea transcrierii și transliterării. Recuperarea imprimografică s-a produs doar pe pagina 1, celelalte doua pagini fiind defective.

Noi birăi (iV) - Signatura 1679/1608

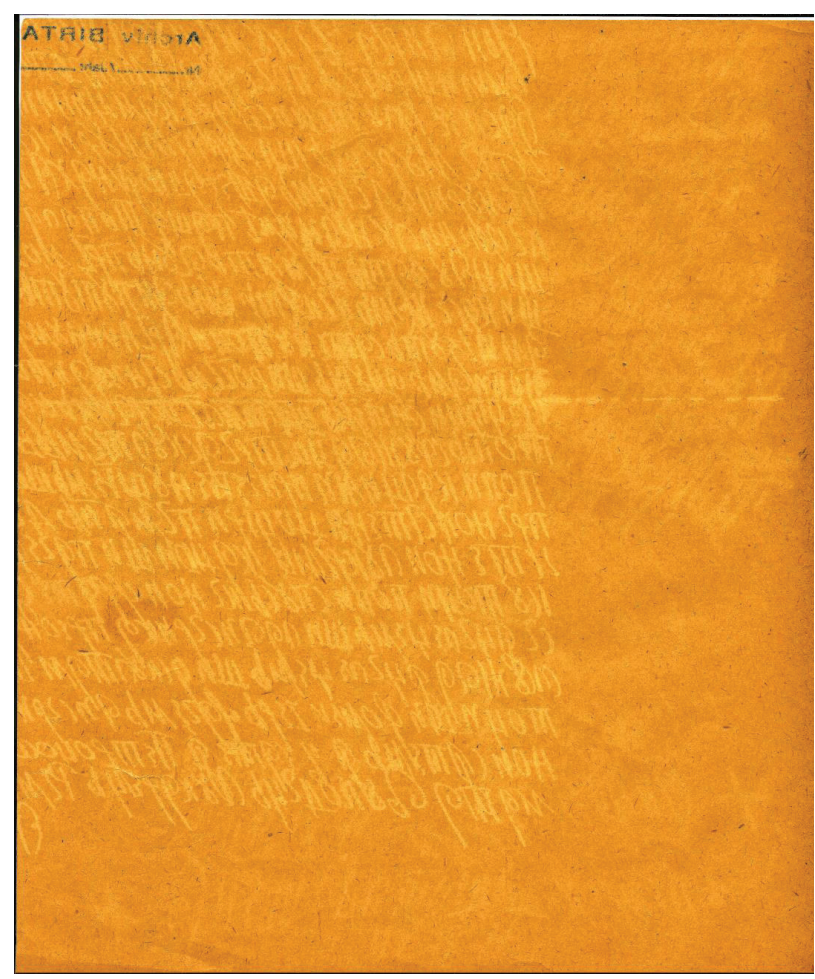

Faza I - transliterarea textului în oglindă 


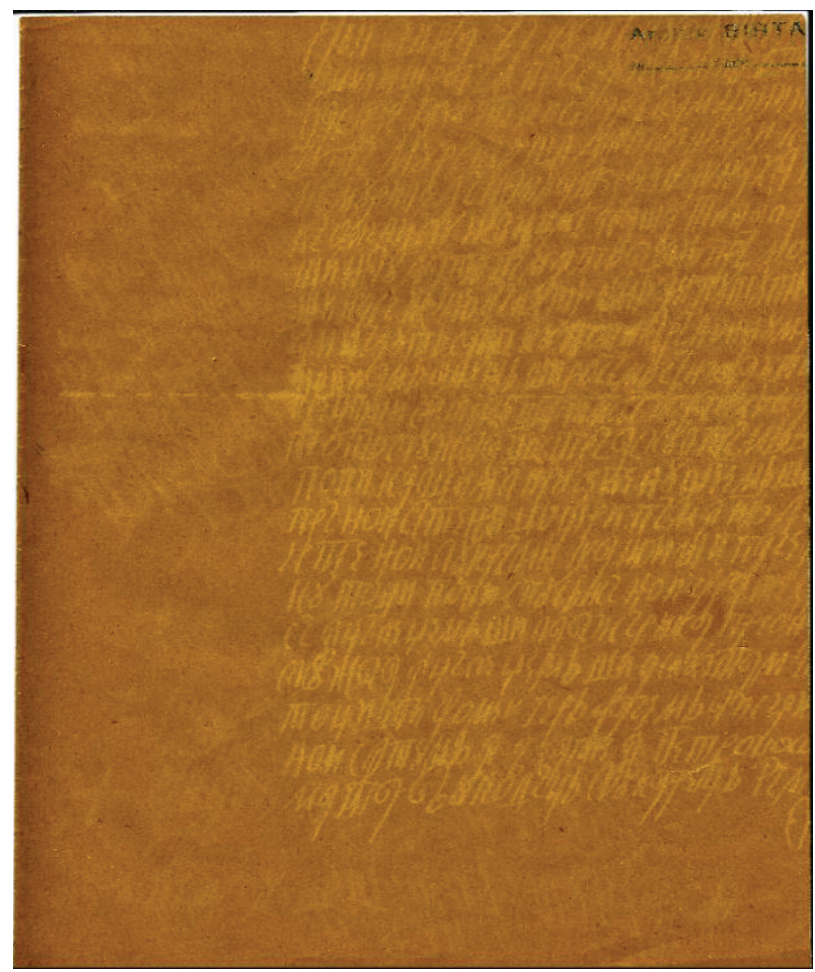

Faza a II-a, transliterarea textului recuperat

\section{Pag. 1}

\begin{tabular}{|c|c|}
\hline 1 & Нон Бнрън 23 к8 М〈н〉БМ४рн шн капн 318 \\
\hline 2 & 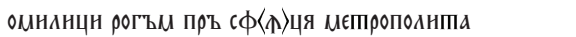 \\
\hline 3 & Васндє алв ППємнсвара кам внннп дъ Пр- \\
\hline 4 & ъспъъ Я̈връшь шн АТпрнжврн к8 пооппє \\
\hline 5 & нБМ४рнАє дъ няМь ашєZаПь \\
\hline 6 & 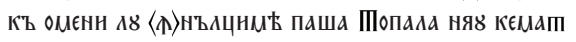 \\
\hline 7 & шн ня8 ААпь ПъМ९Пь Б8нь пръ Мошїє ноъ \\
\hline 8 & 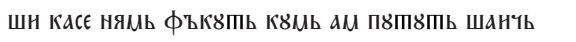 \\
\hline 9 & ам въz४пьь сапє к४ попн яръ нон н४ма папр४ \\
\hline 10 & попн амь ав४пь шн рогъМь Съ нН Аан попн Къ нон \\
\hline 11 & КрєЩНнН СТПєМЬ ШН АнМБъ ворБНМЬ Ка ШН воН \\
\hline 12 & ПОПЬ сА४жБа восПОЬ АсК४АППЪМЬ НОН ворБа \\
\hline 13 & 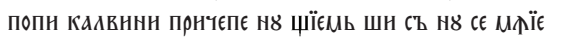 \\
\hline 14 & пръ нон съпенн вощрн ПъМлПь дъспп४Аь \\
\hline 15 & 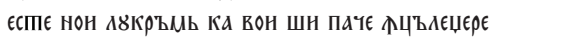 \\
\hline 16 & к8 Пооцн попн сп४сь Къ нон фрапє српєемь \\
\hline 17 & 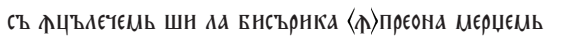 \\
\hline 18 & СА४ЖБА ТЦЪАєџєЩЬ ШН АСКУАППаМ ШН ПААЧє \\
\hline 19 & ПОЧЦН ШН ФОМЕН ТЕрЬ ФАЧЕМЬ АН СЪРНЧН АарЪ \\
\hline 20 & 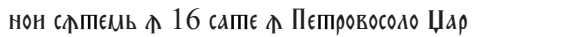 \\
\hline 21 & мапа Пвковъць Пвкарєць Рємєпя \\
\hline
\end{tabular}


Pag. 2

\begin{tabular}{|c|c|}
\hline 1 & Янова Чока Сакаладь ЧевZа Шагь Џнрокь \\
\hline 2 & 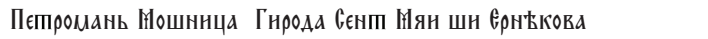 \\
\hline 3 & 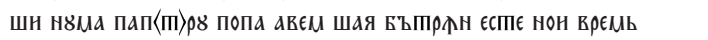 \\
\hline 4 & Попн ка воџрн дацН ноъ Аа фнПъче сапь Попа нон дъМь Ка \\
\hline 5 & 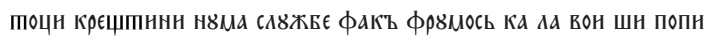 \\
\hline 6 & 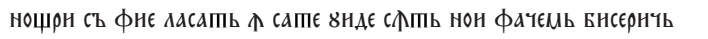 \\
\hline 7 & 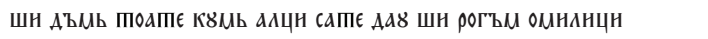 \\
\hline 8 & 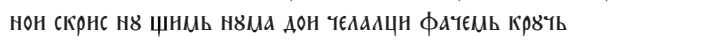 \\
\hline 9 & ШН П४нєМЬ АєџєПЬ КУ ОМєнНє Сь фНМ Аъ цНнерЪ \\
\hline 10 & ворБн шн Сфрця Па Съ нН фачн попн къ М৪Ацн \\
\hline 11 & 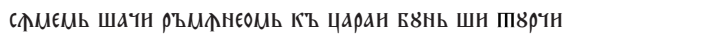 \\
\hline 12 & АОМЕнНЕ СТПЬ ШН БНСЕрНКА Пє С४ФАєПП४АЬ НОСПрУ \\
\hline 13 & 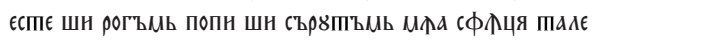 \\
\hline 14 & Шн врєМн вннь нюМь фкнна ха фаца па нон 23 \\
\hline 15 & Бнрън к8 318 нБЩ8рн а ноаспрє шн к8 поццн \\
\hline 16 & 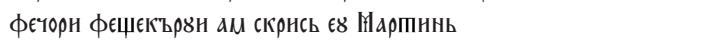 \\
\hline 17 & дяк Пєпровосоло хона Сєпп 27 ан 691 \\
\hline 18 & $\mathrm{~J}_{\Lambda \mathrm{H} \epsilon}$ Гордаш \\
\hline 19 & 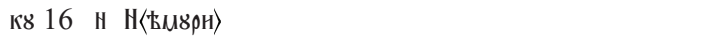 \\
\hline 20 & f Јиона Гвнрш \\
\hline 21 & к8 9 н \\
\hline 22 & Ғ Шандор Негру \\
\hline 23 & к8 18 н \\
\hline 24 & † Яньш Лопншъ \\
\hline 25 & к8 $12 \mathrm{H}$ \\
\hline
\end{tabular}

\section{Pag. 3}

\begin{tabular}{|c|c|c|}
\hline 1 & f $\prod_{\epsilon \Pi \rho \epsilon}$ СаБъ & † ППодорь ВерџєШь \\
\hline 2 & к8 $14 \mathrm{H}$ & к8 $16 \mathrm{H}$ \\
\hline 3 & f Ю̈Онь Ю̆lангра & † фиорь Двцுъ \\
\hline 4 & к8 $8 \mathrm{H}$ & к8 19 Н \\
\hline 5 & f Атанаске Гроза & † Алєкса Дудашь \\
\hline 6 & к8 $23 \mathrm{H}$ & к8 $18 \mathrm{H}$ \\
\hline 7 & † Џврн Двдашь & 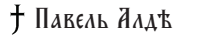 \\
\hline 8 & к8 13 H & к8 $22 \mathrm{H}$ \\
\hline 9 & † Јиїє Крншань & † Шофрон Верль \\
\hline 10 & к8 $7 \mathrm{H}$ & к8 $8 \mathrm{H}$ \\
\hline 11 & f Васнлє Н & † Арон Гвяшь \\
\hline 12 & к8 $6 \mathrm{H}$ & к8 10 H \\
\hline 13 & Ғ Андрєн вць & Ғ Гнццъ Онкншь \\
\hline 14 & к8 $18 \mathrm{H}$ & кв $23 \mathrm{H}$ \\
\hline 15 & † Коспа Жалдєшь & † Васа Пнка \\
\hline 16 & к8 $14 \mathrm{H}$ & к8 $11 \mathrm{H}$ \\
\hline 17 & f Сниа Бвда & \\
\hline 18 & $\kappa 810 \mathrm{H}$ & \\
\hline 19 & † Янъш НҺагъь & \\
\hline 20 & к8 $18 \mathrm{H}$ & \\
\hline 21 & † Пєпрє Кншь & \\
\hline 22 & к8 $5 \mathrm{H}$ & \\
\hline
\end{tabular}




\section{Faza a III-a - Transliterarea textului}

Noi birăi 23 cu neamuri și capi 318, omiliți rogăm pră sfînția metropolita Vasile alu Temisvara, c-am vinit dă prăstă Murăș și dînprijuri cu toate neamurile dă ni-am așezat în nahia ${ }^{7}$ Temisvari cu omenii lu înălțimea pașa Topala. Ne-au chemat și ne-au dat pământ bun pră moșie noă, și case ne-am făcut cum am putut. Ș-aici am văzut sate cu popi iară noi numa patru popi am avut. Și rogăm să ni dai popi, că noi creștini sîntem, și limba vorbim ca şi voi, tot slujba vostră ascultăm. Noi vorba popii călvini pricepe nu știem, și să nu mînie pră noi sătenii voștri, pământ dăstul este, noi lucrăm ca voi, și pace înțălegere cu toți. Popii spus că noi frate sântem să înțălegem și la bisărica împreoună mergem, slujba înțălegem, și ascultam, și place, toți. Și fomei cer facem ai sărici, dară noi sîntem în 16 sate, în Petrovosolo, Gearmata, Bucovăț, Lucareț, Remetea, (pag. $2^{8}$ ) Ianova, Cioca, Sacalaz, Cebza, Șag, Giroc, Petroman, Moșnița, Ghiroda, Sentmiai ${ }^{9}$ și Erneacova. Şi numa patru popa avem, ș-aia bătrâni este.

Noi vrem popi ca voștri, dați nouă la fităce sat, popa noi dăm, ca toți creștinii, numa slujbe facă frumos ca la voi. Și popii noștri să fie lasat în sate unde sînt, noi facem biserici și dăm ${ }^{10}$ toate cum alți sate dau. Și rogăm omiliți, noi scris nu știm, numa doi, celalți facem cruci și punem deget, cu omenie să fim dă ținerea vorbii. Și Sfînția Ta să ni faci popi, că mulți sântem ș-aci rămâne-om, că țara-i bună și Turcii d-omenie sînt, și biserica pe sufletul nostru este. Și rogăm popi, și sărutăm mâna sfânția tale. Și vremi vin, ne-om închina la fața Ta, noi 23 birăi, cu 318 neamuri a noastre, și cu toți feciorii feștecărui.

Am scris eu Martin, diac Petrovoselo, lona sept. 27, an 1691.

Ilie Gordaș cu 16 neamuri, Ilona Guirș cu 9 neamuri, Șandor Negru cu 18 neamuri, Ianăș Lotiș cu 12 neamuri, (pag. 3) Petre Sabău cu 14 neamuri, Ion Mangra cu 8 neamuri, Atanasie Groza cu 23 neamuri, Giuri Dudaș cu 13 neamuri, Ilie Crișan cu 7 neamuri, Vasile Ilia cu 6 neamuri, Andrei Uță cu 18 neamuri, Costa Jaldeș cu 14 neamuri, Sima Luda cu 10 neamuri, Ianăș Neagrău cu 18 neamuri, Petre Chiș cu 5 neamuri, Todor Verdeș cu 16 neamuri, Florea Duță cu 19 neamuri, Alecsa Dudaș cu 18 neamuri, Pavel Aldea cu 22 neamuri, Șofron Verlea cu 8 neamuri, Aron Guiaș cu 10 neamuri, Ghiță Onchiș cu 23 neamuri, Vasa Lica cu 11 neamuri.

\footnotetext{
${ }^{7}$ (Cf. turc.) regiune, privincie

${ }^{8}$ Paginile 2 și 3 lipsesc imprimografic, fiind reconstituite după originalele din arhivă.

${ }^{9}$ Sân Mihai.

${ }^{10}$ Plata impozitelor și a dărilor.
} 


\section{Izvoare}

Arhivele caraşovenești (anii 1010-1748), fonduri feudale, redacția română.

\section{Literatura}

Birta, 2019: I. Birta, Afurisania lui Doja, Reșița, ed. a III-a.

Jovanović, 2000: T. Jovanović, Prepis izvoda Hilandarskog tipika u zbirci Rumunske Akademije

Nauka, Osam vekova Hilandara, Istorija, duhovni život, književnost, umetnost $i$ arhitektura,

Međunarodni naučni skup, oktobar 1998, SANU, Naučni skupovi, knjiga XCV, Odeljenje

istorijskih nauka, knjiga 27, Beograd, 193-201/T. Iovanovici, Transcriere după extrasul tipicului

Hilandar din colecția Academiei Române, Opt secole a Hilandarului, Istorie, viață spirituală,

literatură, artă și arhitectură, Sesiunea internațională de știință, oct. 1998, Academia Sârbă de

Științe și Artă, Sesiuni științifice, tom XCV, Secția științelor istorice, tom. 27, Belgrad, 193-201.

Ivan Birta

\section{PRISUSTVO SRBA U RUMUNSKOM BANATU ZASNOVANO NA DOKAZIMA HEMO-MEHANIČKE IMPRIMOGRAFIJE}

Rezime

Rad donosi nove dokaze o prisutnosti Srba u rumunskom Banatu.

Kao što je već navedeno u časopisu Ishodišta br. 5, njihova prisutnost dokazana je već 1182. godine, dolaskom monaha Ilarija iz Crvije (= Srbija), koji je sagradio samostan u Kavaranu. Njega sledi 1342. g. iguman Elefterije, koji će sagraditi samostan u Zlatici - po hramu svetog Save, te Knez Lazar (Srbin), koji nakon izgradnje samostana Vodice 1371. godine poklanja ovom manastiru 10 sela kao metohe. Sledi ga 1438. godine Knez Milan, koji će sagraditi samostan Kusić, u kome zasedaju srpski redovnici iz Srbije.

1486. g. srpski despot Jovan Branković obdaruje i obitava samostan Partoş, a 1498. godine Dimitrije Iakšić (Srbin) obdaruje kamenu crkvu iz Hodoșa. 
Ovaj rad vrednuje tri dokumenta koja su nastala na osnovi kemo-mehaničke imprimografije:

1. Rukopis popa Janku iz Jaza - 27. jul 1604. g.;

2. Rukopis Gavrila, egumena iz samostana Sveti Đurađ u Karansebešu - 23. septembar 1608. g.;

3. Rukopis đakona Martina iz Petrovog Sela - 27. septembar 1691. g. koji se odnosi na jednu od velikih seoba Srba.

Ključne reči: Kavaran, knez Lazar, knez Milan, Dimitri Iakšić, imprimografija, Jovan Branković, Srbija, Sveti Sava. 